\title{
Guillain-Barré syndrome: the most common but difficult to diagnose acquired polyneuropathy
}

\author{
Zespół Guillaina-Barrégo - najczęstsza, ale trudna do rozpoznania polineuropatia nabyta
}

'Department of Paediatrics, School of Medicine with the Division of Dentistry in Zabrze, Medical University of Silesia in Katowice, Zabrze, Poland. Head of the Department: Professor Katarzyna Ziora, MD, PhD 2Department of Internal Medicine, Diabetes and Nephrology, School of Medicine with the Division of Dentistry in Zabrze, Medical University of Silesia in Katowice, Zabrze, Poland. Head of the Department: Professor Władysław Grzeszzzak, MD, PhD

${ }^{3}$ Paediatric Ward, Independent Public Health Care Facility, Multidisciplinary Hospital in Jaworzno, Jaworzno, Poland. Head of the Ward: Wiesław Więckowski, MD, PhD

Correspondence: Majka Jaszzzura, Department of Paediatrics, School of Medicine with the Division of Dentistry in Zabrze, Medical University of Silesia in Katowice, 3-go Maja 13-15, 41-800 Zabrze, Poland, tel.: +4832370 43 44, e-mail: tleni@wp.pl

\begin{abstract}
Guillain-Barré syndrome, an acute autoimmune inflammatory polyneuropathy, is the most frequent cause of acute onset flaccid paresis. Various sources report its incidence of 1-4/100,000 individuals per year. A triggering factor in most cases is a previous respiratory or gastrointestinal tract infection. Apparently, via the molecular mimicry mechanism, antibodies against bacterial or viral antigens are formed and bind with similar epitopes in the peripheral nervous system. The clinical picture is highly diversified and may range from slight muscle weakness within the feet to full-blown tetraplegia with respiratory failure. The typical course of the disease consists of the progressive phase, the plateau phase and the recovery phase, lasting even 6-14 months. The diagnosis is based on the criteria published in 1978. They encompass clinical signs and symptoms as well as electrophysiological and pathomorphological parameters. A crucial sign leading to the diagnosis is progressive flaccid paresis of more than one limb with the absence or reduction of tendon reflexes. The treatment involves plasma exchange and intravenous immunoglobulin. The use of glucocorticosteroids, interferon beta, rituximab and eculizumab requires further investigation. Moreover, symptomatic treatment, kinesiotherapy, respiratory physiotherapy, thromboembolic prophylaxis, nutritional therapy and pain management are also very important. Prognosis is in most cases favourable, but mortality ranges from 4 to $15 \%$ despite appropriate treatment and intensive care. The aim of this article is to sum up current information about Guillain-Barré syndrome and to emphasise the relevance of this disease, which requires further investigation in both paediatric and adult patients.
\end{abstract}

Keywords: Guillain-Barré syndrome, diagnosis, work-up, treatment

Zespół Guillaina-Barrégo, ostra zapalna polineuropatia o charakterze autoimmunologicznym, jest najczęstszą przyczyną wiotkiego niedowładu kończyn o ostrym początku. Według różnych źródeł zapadalność wynosi 1-4/100 000 ludności na rok. Czynnikiem wyzwalającym w większości przypadków jest przebyta wcześniej infekcja układu oddechowego lub przewodu pokarmowego. Prawdopodobnie na drodze mimikry molekularnej dochodzi do powstawania przeciwciał przeciwko antygenom bakteryjnym lub wirusowym, które wiążą się z podobnymi epitopami w obwodowym układzie nerwowym. Obraz kliniczny jest niezwykle różnorodny, waha się od niewielkiego osłabienia siły mięśniowej w obrębie stóp aż do pełnej tetraplegii z niewydolnością oddechową. Typowy przebieg choroby obejmuje okres narastania objawów, plateau i fazę zdrowienia trwającą nawet 6-14 miesięcy. W rozpoznaniu stosuje się kryteria opublikowane w 1978 roku, które obejmują objawy kliniczne, kryteria elektrofizjologiczne i patomorfologiczne. Objawem koniecznym do rozpoznania jest postępujący wiotki niedowład więcej niż jednej kończyny ze zniesieniem lub osłabieniem odruchów ścięgnistych. W leczeniu stosuje się plazmaferezę oraz dożylne wlewy immunoglobulin. Natomiast zastosowanie glikokortykosteroidów, interferonu beta, rituksymabu i ekulizumabu wymaga dalszych badań. Niezwykle istotne są również: leczenie objawowe, kinezyterapia, fizjoterapia oddechowa, profilaktyka zakrzepowo-zatorowa, leczenie żywieniowe oraz postępowanie przeciwbólowe. W większości przypadków rokowanie jest dość dobre, ale śmiertelność, pomimo prawidłowego leczenia w warunkach intensywnego nadzoru, wynosi 4-15\%. Poniższa praca ma na celu podsumowanie bieżących informacji na temat zespołu Guillaina-Barrégo oraz podkreślenie istotności zagadnienia, które wymaga dalszych badań zarówno w populacji pacjentów pediatrycznych, jak i dorosłych. 


\section{INTRODUCTION}

G uillain-Barré syndrome (GBS) is an acute inflammatory autoimmune polyneuropathy, first described in $1916^{(1)}$. It is the most frequent cause of acute onset flaccid paresis. A triggering factor is in most cases a previous infection. The syndrome presents with symmetrical ascending muscle weakness and absence of tendon reflexes, and may result in acute flaccid paraor tetraplegia, cranial nerve palsy and respiratory failure. The current knowledge indicates that GBS encompasses several subtypes of acute neuropathy. The following forms of the disease have been distinguished ${ }^{(2,3)}$ :

- a classical form - acute inflammatory demyelinating polyneuropathy (AIDP) accounting for approximately 90\% of GBS cases in Europe;

- acute motor axonal neuropathy (AMAN) - approximately $5 \%$ of cases;

- acute motor-sensory axonal neuropathy (AMSAN);

- a pharyngeal-cervical-brachial variant - bulbar palsy that leads to dysphagia and dysarthria;

- a paraparetic variant;

- Miller Fisher syndrome, which is a very rare variant that involves a triad of symptoms in the form of external ophthalmoplegia, ataxia and areflexia;

- Bickerstaff's brainstem encephalitis with prevailing consciousness disorders and hyperreflexia in 1/3 of cases;

- acute pandysautonomia (the least common) with generalised autonomic system failure, the most stable symptom of which is orthostatic hypotonia that leads to syncope episodes.

\section{EPIDEMIOLOGY AND AETIOLOGY}

Guillain-Barré syndrome may occur at any age with the incidence slightly increasing with age. Various sources report its incidence of 1-4/100,000 individuals per year, which constitutes approximately 800 new cases annually ${ }^{(4-6)}$. In the paediatric population ( $0-15$ years of age), the incidence ranges from 0.34 to 1.34 per 100,000 per year. The latest studies show that GBS is slightly more common in males $(\mathrm{M}: \mathrm{F} 1.5: 1)^{(1,7,8)}$.

The disease is believed to be autoimmune. In $2 / 3$ of patients, it is preceded with a mild viral infection (cytomegalovirus, CMV; Epstein-Barr virus, EBV; influenza A virus) or, more rarely, with a bacterial infection (Campylobacter jejuni, Mycoplasma pneumoniae, Haemophilus influenzae) of the respiratory or gastrointestinal tract, with a respiratory infection being predominant (50-70\%) over a gastrointestinal one $(7-14 \%)^{(2,3,9,10)}$. The latest reports indicate that GBS symptoms may develop in patients infected with Zika virus $^{(1,8)}$. Infection, which usually occurs several weeks before the onset of the first neurological symptoms, induces, via the molecular mimicry mechanism, the formation of antibodies against bacterial or viral antigens which bind
Damage to the myelin sheath is probably caused not only by the humoral response, but also by the cell-mediated one in the presence of macrophages. Activated T-helper cells interact with antigens on the surface of Schwann cells or myelin sheath. Also, abnormal T-cell function is taken into account ${ }^{(11)}$. An undoubted pathogenic relationship has been determined for gastrointestinal infection with Campylobacter jejuni. The mechanism of axonal injury secondary to $C$. jejuni infection is associated with the presence of enzymes that synthesise ganglioside-mimicking structures (GM1, GM1a, GM1b), present in the peripheral nerves, and with the inflow of macrophages to the axonmyelin interface, particularly in the region of the nodes of Ranvier ${ }^{(9,12)}$. Campylobacter jejuni infection may precede each GBS subtype, but antibodies against the aforementioned gangliosides are usually detected (even in over $50 \%$ of cases) in acute motor axonal neuropathy (AMAN). A similar mechanism may be observed for viral infections, but this has not been documented that well. It is thought that EBV infection is associated with milder GBS course, whilst CMV infection is related with more frequent cranial nerve involvement, respiratory failure and sensory fibre damage $e^{(2,7)}$.

Certain reports suggest that, besides the production of antibodies against single gangliosides, GBS is also characterised by the formation of antibodies against ganglioside complexes, which are directed against other epitopes and have more potent proinflammatory properties ${ }^{(13)}$.

Moreover, the relationship of this syndrome with vaccination has also been reported; a particularly evident increase in its incidence was observed in 1976 after influenza (socalled swine flu) vaccination ${ }^{(1,14)}$. No relationships with other common vaccines have been noted. Guillain-Barré syndrome has also been observed after general anaesthesia, childbirth, and in the course of neoplasms (lung cancers, lymphomas), HIV infection, Lyme disease and sarcoid$\mathrm{osis}^{(4)}$. A triggering factor remains unknown in approximately $30 \%$ of patients. It must be underlined that this is not a genetic disease. Rarely reported familial cases may result from common exposure to triggering factors or genetic predisposition (individual susceptibility). To date, however, no genetic or environmental factor that could affect the susceptibility to this disease has been identified ${ }^{(10)}$.

\section{CLINICAL PICTURE}

The disease is monophasic in $90 \%$ of patients and can become chronic or recurrent in the remaining cases. Neurological deficits usually occur within 2-28 days after the onset ${ }^{(15)}$. Tab. 1 presents the entire spectrum of signs and symptoms that might develop in $\mathrm{GBS}^{(16)}$. The typical course consists of the progressive phase (up to 3 weeks in $80 \%$ of patients), the plateau phase (10-14 days) and the recovery phase, lasting even 6-14 months.

Initially, patients frequently complain about interscapular or lumbar pain, probably resulting from nerve root 
oedema and meningeal irritation. At this time, physical examination reveals neck stiffness and positive Kernig's sign. Other symptoms are a result of all types of dysaesthesias (superficial, deep, pain, and temperature), but they are usually less pronounced than motor abnormalities. Data on the occurrence of pain in the course of GBS are highly divergent; various authors report its occurrence in 3-89\% of cases ${ }^{(6,17,18)}$. However, attention should be paid to the fact that pain might be the leading symptom in the paediatric population. Painful paraesthesia or numbness may precede motor disorders. Paresis usually starts from the lower extremities and extends to the upper limbs and corpus muscles. As it progresses, deep reflexes become weaker or absent. The fact that these reflexes may initially be preserved (they disappear within 1 week of the onset in most patients) is a reason of diagnostic difficulties. Intercostal and phrenic nerve involvement leads to respiratory failure that requires treatment in intensive care settings. Cranial nerve involvement (facial, glossopharyngeal, vagus, extraocular, trigeminal nerves) is observed in approximately $30-50 \%$ of patients. Autonomic signs and symptoms develop in approximately $30 \%$ of patients (Tab. 1). If they are associated with the cardiovascular system, they may be life-threatening; these mainly include permanent or episodic hypertension and arrhythmia ${ }^{(6,19)}$. Moreover, socalled cerebral symptoms, such as anxiety, confusion, agitation and hallucinations, may also occur in the acute phase of the disease ${ }^{(20)}$.

Based on the differences in the clinical picture, i.e. the distribution of paresis and function of involved fibres, certain disease subtypes have been distinguished. The classical form, i.e. acute inflammatory demyelinating polyneuropathy (AIDP), progresses to symmetrical muscle weakness

\begin{tabular}{|c|c|}
\hline Motor disorders & $\begin{array}{l}\text { - Symmetrical limb weakness } \\
\text { - Neck muscle weakness } \\
\text { - Respiratory muscle weakness } \\
\text { - Cranial nerve involvement: III-VII, IX-XII } \\
\text { - Areflexia } \\
\text { - Muscle weakness }\end{array}$ \\
\hline Dysaesthesia & $\begin{array}{l}\text { - Pain } \\
\text { - Numbness, paraesthesia } \\
\text { - Impaired sense of position, vibration and touch } \\
\text { - Ataxia }\end{array}$ \\
\hline $\begin{array}{l}\text { Autonomic system } \\
\text { disorders }\end{array}$ & $\begin{array}{l}\text { - Sinus tachycardia/bradycardia } \\
\text { - Other arrhythmias } \\
\text { - Hypertension } \\
\text { - Orthostatic hypotonia } \\
\text { - High BP and HR oscillations } \\
\text { - Sialorrhoea } \\
\text { - Hyperhidrosis } \\
\text { - Urinary retention } \\
\text { - Dysphagia } \\
\text { - Constipation } \\
\text { - Gastrointestinal peristalsis disorders }\end{array}$ \\
\hline Other & $\begin{array}{l}\text { - Optic disc oedema } \\
\text { - Headache } \\
\text { - Confusion } \\
\text { - Motor agitation }\end{array}$ \\
\hline
\end{tabular}

Tab. 1. Clinical symptoms of GBS in the lower extremities, areflexia and various dysaesthesias. In the axonal form (AMAN), the clinical course is similar, but there are no dysaesthesias. Acute motorsensory axonal neuropathy (AMSAN) is identified when an AMAN patient develops dysaesthesias ${ }^{(21)}$. Due to early muscle atrophy, the axonal forms present worse prognosis. Additionally, axonal forms are more severe, more frequently progress to respiratory failure, and result in longer cranial nerve involvement ${ }^{(22,23)}$. Moreover, a pharyngeal-cervical-brachial variant is also distinguished. It is characterised by ophthalmoplegia, palsy of the muscles in the face, neck and arms, and bulbar palsy, with paresis of the lower extremities being uncommon. The paraparetic form of GBS mimics cauda equina syndrome (weakness in the lower extremities, saddle anaesthesia, and bowel and bladder dysfunction). Miller Fisher syndrome is a mild GBS form that can potentially recur. It is characterised by ophthalmoplegia with ptosis, limb ataxia, balance disorders and paraesthesia. Anti-GQ1b antibodies are much more often detected in patients with this type of the disease.

The clinical picture of GBS is highly diversified and may range from slight muscle weakness within the feet to fullblown tetraplegia with respiratory failure. Prognosis is relatively good in most cases. There is a clear relationship between the ultimate neurological deficit and the severity of paresis in the acute phase of the disease, the duration of the plateau phase and, sometimes, mechanical ventilation. Factors of poor prognosis include preceding diarrhoea, age $>50$ years, and considerable axonal changes ${ }^{(1,15)}$. Symptoms relatively frequently recur with preceding infection or vaccination, and may occur even many years (4-36) after the primary episode $\mathrm{e}^{(6)}$.

\section{DIAGNOSIS}

The diagnosis of GBS is based on the criteria published in 1978. They encompass clinical signs and symptoms as well as electrophysiological and pathomorphological parameters. A crucial sign leading to the diagnosis is progressive flaccid paresis of more than one limb with the absence or reduction of tendon reflexes. Furthermore, there are certain signs and symptoms that are suggestive of GBS. They include: progression of signs and symptoms for several days to several weeks, symmetrical abnormalities, slight dysaesthesias, cranial nerve involvement, the beginning of the recovery phase within 2-4 weeks after the cessation of disease progression, autoimmune disorders, and no fever at onset.

Cerebrospinal fluid (CSF) analysis is significant in the diagnostic workup as it shows an elevated protein level without pleocytosis in approximately $80 \%$ of patients. The CSF protein concentration may exceed $2 \mathrm{~g} / \mathrm{L}$ with normal cytosis that does not exceed 10 cells per $1 \mathrm{~mm}^{3}$. The CSF protein level may be normal if puncture is conducted in the first days of the disease. A peak increase is noted 4-6 weeks after the onset, and the elevated levels may 
persist for many months ${ }^{(23)}$. Sometimes, the typical picture of GBS can be accompanied by cytosis of 10-100 cells $/ \mathrm{mm}^{3}$. This does not preclude GBS, but other diseases (infections, neoplasms, sarcoidosis) must be considered as well.

Electrophysiological examination of nerves and muscles reflects the type of a pathological process in nerves and helps distinguish a neuropathy with axonal injury from a demyelinating disease. Usually, any abnormalities are the most pronounced at 2 weeks after the onset of muscle weakness ${ }^{(10)}$. It is recommended to perform a neurographic study of 3 sensory nerves and 3 motor nerves with the assessment of F-wave and H-reflex in the tibial nerves ${ }^{(7)}$. Electrophysiological criteria include: prolonged latency or no F-wave, and slower or blocked conduction. In the first days after the onset, neurography may be normal. That is why, when in doubt, a re-evaluation is recommended after 1-2 weeks. The greatest diagnostic difficulties are associated with cases without nerve excitability, when electrophysiological investigation is incapable of distinguishing whether the block results from demyelination or axonal degeneration.

Nerve biopsy has no diagnostic relevance. Depending on the type of the disease, it may reveal demyelination with macrophage and lymphocyte infiltration, demyelination with axonal degeneration or only axonal degeneration ${ }^{(24)}$. The level of antiganglioside antibodies, which are detected in approximately $50 \%$ of patients, may be a useful parameter to confirm the diagnosis, especially in atypical cases ${ }^{(8)}$.

\section{Differential diagnosis}

Differential diagnosis is presented in Tab. $2^{(23)}$.

\section{TREATMENT}

Each patient with suspected GBS should be sent to hospital as the dynamics of disease progression and the severity of the signs and symptoms cannot be predicted. In the progression phase, heartrate, blood pressure, respiratory efficiency and bulbar sings must be monitored. It is also equally important to prevent complications (pneumonia, other infections, pressure ulcers, etc.), provide adequate care, nutrition and long-term rehabilitation.

Plasma exchange (PE) is a treatment method with efficacy proven in randomised clinical trials ${ }^{(6,25,26)}$. It has been shown that it shortens the duration of immobilisation and the use of mechanical ventilation as well as increases the rate of patients who regain muscle strength within a year ${ }^{(15)}$. Plasma exchange belongs to invasive treatment methods. That is why, it should be considered only for patients with at least 1 of the following sings: respiratory failure, bulbar palsy (risk of aspiration) and inability to ambulate $e^{(6,27)}$. Treatment should be implemented within the first 2 weeks after the onset. It is effective when appropriate amount of plasma is exchanged ( $40-50 \mathrm{~mL} / \mathrm{kg}$ body weight). Plasma a $5 \%$ albumin solution being used as the replacement fluid. Blood pressure and electrocardiogram must be monitored during the procedure. Complete blood count must be evaluated before and after the procedure, and immunoglobulin $\mathrm{G}$ (IgG) must be assayed after the procedure; potential deficiencies should be corrected. Plasma exchange may be contraindicated in cases of severe autonomic disorders or electrolyte imbalances and when stable concentrations of patient's other drugs must be maintained. Complications include hypotension, bacteraemia, hypocalcaemia, and coagulation disorders.

Intravenous immunoglobulin (IVIG) at a dose of $0.4 \mathrm{~g} / \mathrm{kg}$ body weight for 5 consecutive days is as effective as PE in severe cases. Due to similar efficacy, IVIG has become the method of choice in numerous neurological centres due to the safety benefit and easier application. Some authors recommend the administration of the entire dose $(2 \mathrm{~g} / \mathrm{kg}$ body weight) within 2 days, particularly in younger patients with no cardiac comorbidity and with normal renal function ${ }^{(28)}$. Obtaining higher immunoglobulin doses in a short time may entail a better therapeutic effect, which has been observed in paediatric patients ${ }^{(15)}$. Intravenous immunoglobulin is preferred in children with GBS. Severe, although rare, adverse effects of IVIG include: thromboembolic complications (stroke, myocardial infarction, deep vein thrombosis), acute tubular necrosis and aseptic meningitis. Also, muscle

\begin{tabular}{|c|c|}
\hline $\begin{array}{l}\text { Metabolic } \\
\text { polyneuropathies }\end{array}$ & $\begin{array}{l}\text { In the course of: } \\
\text { - Porphilia } \\
\text { - Diabetes } \\
\text { - Hypophosphataemia, hypokalaemia, } \\
\text { hypermagnesaemia } \\
\text { - Beriberi (vitamin } B_{1} \text { deficiency) }\end{array}$ \\
\hline Channelopathies & $\begin{array}{l}\text { - Hyper or hypokalaemic periodic paralysis } \\
\text { - Andersen-Tawil syndrome } \\
\text { - Acquired (autoaggression) }\end{array}$ \\
\hline $\begin{array}{l}\text { Infection-related } \\
\text { neuropathies }\end{array}$ & $\begin{array}{l}\text { - Lyme disease } \\
\text { - Brucellosis } \\
\text { - Polio } \\
\text { - Rabies } \\
\text { - HIV } \\
\text { - Enterovirus } 71 \text { (polio-like syndrome) } \\
\text { - Arbovirus (Japanese encephalitis) }\end{array}$ \\
\hline Poisoning & $\begin{array}{l}\text { - With organic solvents } \\
\text { - With heavy metals } \\
\text { - With neurotoxin-containing fish and crustaceans }\end{array}$ \\
\hline Systemic diseases & $\begin{array}{l}\text { - Systemic lupus erythematosus } \\
\text { - Rheumatoid arthritis } \\
\text { - Polyarteritis nodosa }\end{array}$ \\
\hline Cancer-related GBS & $\begin{array}{l}\text { - Lung cancer } \\
\text { - Hodgkin disease } \\
\text { - Lymphomas } \\
\text { - Myeloma }\end{array}$ \\
\hline Other & $\begin{array}{l}\text { - Myasthenia gravis } \\
\text { - Myasthenic syndromes } \\
\text { - Botulism } \\
\text { - Myositis } \\
\text { - Spinal cord/brainstem pathology } \\
\text { - Sarcoidosis } \\
\text { - Paraneoplastic syndromes }\end{array}$ \\
\hline
\end{tabular}

Tab. 2. Differential diagnosis 
pain, fever, shivers, headache, nausea, vomiting, elevated liver enzyme levels and rash may occur.

To date, no reports have confirmed benefits from the combination of the two aforementioned methods. Glucocorticosteroids (GCS) are not routinely used in GBS treatment. In selected cases, methylprednisolone is allowed after IVIG, but this requires further investigation ${ }^{(29)}$.

The experience with PE and IVIG concerns patients with severe GBS, while treatment of mild forms remains an open issue. The available literature indicates that treatment is not necessary in patients able to walk on their own in the $2^{\text {nd }}$ week after the onset. After clinical improvement or in the stabilisation phase, the disease may exacerbate again in approximately $10 \%$ of patients. It this situation, treatment must be repeated. Some patients with recurrences may develop chronic demyelinating polyneuropathy.

Potential new treatment methods include interferon beta and monoclonal antibodies: rituximab and eculizumab. However, as of today, there are no studies supporting their efficacy ${ }^{(8)}$.

Furthermore, symptomatic treatment is very important in GBS. Patients should be treated in centres with available intensive care in case of respiratory failure. Patients may require life support (ventilator) for several or a dozen or so days. For the entire time of mechanical ventilation, the patient should undergo respiratory physiotherapy. Also, the need proper hydration, mucolytic agents and suction of respiratory tract secretion must be taken into account. In immobilised patients, thromboembolic prophylaxis should be implemented. Full enteral or, if required, parenteral nutrition is essential. Autonomic disorders may occur in even $60 \%$ of patients. That is why constant monitoring is required, and cardiac electrostimulation may be needed, for example, in bradyarrhythmia. In symptomatic treatment of changeable blood pressure, short-acting drugs should be administered. Pain management (musculoskeletal pain, neuropathic pain) is very important and should be conducted in accordance with the so-called analgesic ladder. If pain persists, adjuvants should be used (carbamazepine, amitriptyline, gabapentin and GCS). Rehabilitation should be implemented from the very onset of the disease. The initial passive exercises are followed by active ones with progressive improvement.

\section{PROGNOSIS}

The statistical data provided below are the best confirmation of the fact that GBS is a significant clinical threat that requires further investigation, studies on its pathogenesis and a search for new treatment options. Most patients fully recover or suffer only minor neurological deficits that do not impair their functioning significantly. It must be remembered, however, that the disease leads to permanent and considerable motor disability in approximately $20 \%$ of patients. During the recovery period, patients faster regain function in the upper than in lower limbs. Also, upper limb dysfunction after one-year rehabilitation is half as common as lower limb dysfunction. Symptoms of chronic fatigability are reported by $60-70 \%$ of patients. Its late disappearance carries a risk of fixed disorders of this type. It also seems that age is a negative prognostic factor, affecting the dynamics of symptom regression, both in the paediatric and adult population. Mortality in GBS amounts to $4-15 \%$ despite symptomatic treatment, immunotherapy and almost unlimited access to intensive care ${ }^{(3,5,27)}$.

\section{Conflict of interest}

Authors do not report any financial or personal connections with other persons or organisations, which might negatively affect the contents of this publication and/or claim authorship rights to this publication.

\section{References}

1. Hughes RAC, Cornblath DR, Willison HJ: Guillain-Barré syndrome in the 100 years since its description by Guillain, Barré and Strohl. Brain 2016; 139: 3041-3047.

2. Pritchard J: What's new in Guillain-Barré syndrome? Pract Neurol 2006; 6: 208-217.

3. Szwed K, Mazur-Melewska K, Figlerowicz M et al.: Przebieg kliniczny i odległe następstwa zespołu Guillaina-Barrégo u dzieci. Pediatr Pol 2012; 87: 47-53.

4. Kozubski W, Liberski PP (eds.): Neurologia. Podręcznik dla studentów medycyny. Wydawnictwo Lekarskie PZWL, Warszawa 2011: 534-537.

5. Hughes RA, Wijdicks EF, Barohn R et al.; Quality Standards Subcommittee of the American Academy of Neurology: Practice parameter: immunotherapy for Guillain-Barré syndrome: report of the Quality Standards Subcommittee of the American Academy of Neurology. Neurology 2003; 61: 736-740.

6. Kopytko D, Kowalski PM: Guillain-Barré syndrome - literature overview. Pol Ann Med 2014; 21: 158-161.

7. Hughes RA, Cornblath DR: Guillain-Barré syndrome. Lancet 2005; 366: 1653-1666.

8. Esposito S, Longo MR: Guillain-Barré syndrome. Autoimmun Rev 2017; 16: 96-101.

9. Kopyta I, Domaradzka E: Zespół Guillain-Barré u dzieci hospitalizowanych na Oddziale Pediatrii i Neurologii Wieku Rozwojowego w latach 2011-2014. Neurol Dziec 2016; 25: 53-59.

10. Willison HJ, Jacobs BC, von Doorn PA: Guillain-Barré syndrome. Lancet 2016; 388: 717-727.

11. Pritchard J, Makowska A, Gregson NA et al.: Reduced circulating CD4+CD25+ cell populations in Guillain-Barré syndrome. J Neuroimmunol 2007; 183: 232-238.

12. Yuki N, Koga M: Bacterial infections in Guillain-Barré and Fisher syndromes. Curr Opin Neurol 2006; 19: 451-457.

13. Notturno F, Luciani M, Caporale CM et al.: Antibodies to ganglioside complexes in Guillain-Barré syndrome: clinical correlates, fine specificity and complement activation. Int J Immunopathol Pharmacol 2009; 22: 437-445.

14. Langmuir AD, Bregman DJ, Kurland LT et al.: An epidemiologic and clinical evaluation of Guillain-Barré syndrome reported in association with the administration of swine influenza vaccines. Am J Epidemiol 1984; 119: 841-879.

15. Drac H: Ostra zapalna polineuropatia demielinizacyjna i aksonalna - zespół Guillaina-Barrégo. Pol Przegl Neurol 2009; 5: 61-67.

16. Seneviratne U: Guillain-Barré syndrome. Postgrad Med J 2000; 76: 774-782. 
17. Drac H: Ostre zapalne poliradikuloneuropatie. In: Kozubski W, Liberski P (eds.): Choroby układu nerwowego. Wydawnictwo Lekarskie PZWL, Warszawa 2004: 295-298.

18. Ruts L, van Koningsveld R, Jacobs BC et al.: Determination of pain and response to methylprednisolone in Guillain-Barré syndrome. J Neurol 2007; 254: 1318-1322.

19. Maier H, Schmidbauer M, Pfausler B et al.: Central nervous system pathology in patients with the Guillain-Barré syndrome. Brain 1997; 120: 451-464.

20. Weiss $H$, Rastan V, Müllges $W$ et al.: Psychotic symptoms and emotional distress in patients with Guillain-Barré syndrome. Eur Neurol 2002; 47: 74-78.

21. Lipowska M, Kwieciński H: Zespół Guillaina-Barrégo. Przew Lek 2006; 9: 59-65.

22. Vucic S, Kiernan MC, Cornblath DR: Guillain-Barré syndrome: an update. J Clin Neurosci 2009; 16: 733-741.

23. Michałowska M: Zespół Guillaina-Barrégo. Postępy Nauk Med 2009; 22: 889-893.
24. Honavar M, Tharakan JK, Hughes RA et al.: A clinicopathological study of the Guillain-Barré syndrome. Nine cases and literature review. Brain 1991; 114: 1245-1269.

25. Raphaël JC, Chevret S, Hughes RA et al.: Plasma exchange for Guillain-Barré syndrome. Cochrane Database Syst Rev 2002; (2): CD001798.

26. Mazur K, Kanik A, Kozłowska J et al.: Zastosowanie plazmaferezy w praktyce klinicznej. Podsumowanie doświadczeń własnych w świetle aktualnych wytycznych. Nefrol Dial Pol 2017; 21: 1-6.

27. Kwieciński H: Intensywna terapia w zespole Guillain-Barré. Med Dypl 2002; wyd. spec. IV: 58-60.

28. Dalakas MC: Intravenous immunoglobulin in the treatment of autoimmune neuromuscular diseases: present status and practical therapeutic guidelines. Muscle Nerve 1999; 22: 1479-1497.

29. van Doorn PA, van Koningsveld R: Immunotherapy for Guillain-Barré syndrome. Lancet Neurol 2004; 3: 84. 